\title{
The litany of suffering is still heard but not louder: a case study of clinical supervision to school libraries in Indonesia's four provinces
}

\author{
L. SULISTYO-BASUKI \\ Professor, Department of Library and information Science \\ Faculty of Humanities, Universitas Indonesia \\ Jakarta, Indonesia
}

\begin{abstract}
From 2002 through 2004, the National Library of Indonesia distributed block grants to 250 school libraries in the province of Central Java scattered in 10 districts, 150 school libraries in West Nusa Tenggara for 7 districts, 125 school libraries in South Sumatera in 5 districts while in the province of Bangka Belitung only to one municipality covering 25 school libraries. For three years, a school library which serves only one school received a block grant of 19 million rupiahs or approximately US \$2000, while (multiple) school library which serves two or more schools received 29 million rupiahs or around US 3200 all for books. Beside that, there are trainings for library staffs conducted at the province capital as well as at the districts and supervision from the National Library. After three year implementation, the National Library set up two independent teams to evaluate the school library performance, block grant awardees. The first team consists of five consultant on education and librarianship while the second one is an independent consultant bureau. Among the findings are the rise of book usages among school children, rising initiatives among teacher cum teacher in charge of library to correlate the library activities with the class programme and communities' activities, the provision of separate building for school library especially in South Sumatera. However there anxieties on the continuation of the school libraries after the project is over, as not all grant-receiving-districts have enough budget to provide finances for the school library operations after the project is over.
\end{abstract}

\section{Introduction}

The National Library of Indonesia (hereafter called NLI) has various objectives, one of them is to assist the development of libraries in Indonesia. In order to develop school libraries NLI launched a project for developing school and public libraries. The project is a part of implementation phase as agreed between the Government of Indonesia and the World Bank. The loan is a soft one, a part of Learning and Innovation Loan.

In accord with NLI vision in empowering library to support formal education and life long learning, NLI created a project called Project for the Development of Public and School Libraries in Indonesia with the concept to utilize community and school libraries to support life long learning. For the would-be-block-grant-receivers, NLI appointed three provinces, each one representing an area of Indonesia. Those are South Sumatera representing western Indonesia, Central Java representing Central Indonesia [sic] and West Nusa Tenggara representing eastern Indonesia. Latter on Bangka-Beltinug became a new province parted from South Sumatera.

The requirements for the receiving school library are as follows: 
- The school library has good relations with the surrounding communities such as with the mass organisations, boy and girl-scout movement, etc.

- The people in charge of the library possessed at least minimum graduates of Junior High School (class 12) ${ }^{1}$

- The minimum library space is 9 meters square

- The school has been existed for at least one year

- The minimum collection is 50 books excluding textbook and book packages distributed by the government.

- The student population is least 100 students.

The selection is conducted by Provincial Library and decided by NLI. Although the project covers also community libraries, this paper concentrates mainly to school libraries.

Table 1. Block grant receiver for school libraries.

\begin{tabular}{|l|l|l|l|}
\hline$\#$ & Province & $\begin{array}{l}\text { Number } \\
\text { of districts }\end{array}$ & $\begin{array}{l}\text { Number of } \\
\text { school } \\
\text { libraries }\end{array}$ \\
\hline 1 & South Sumatera & 5 & 125 \\
\hline 2 & Bangka Belitung & 1 & 25 \\
\hline 3 & Central Java & 10 & 250 \\
\hline 4 & West Nusa Tenggara & 6 & 150 \\
\hline \multicolumn{3}{|c|}{ Source : Library development Project NLI (2004) }
\end{tabular}

The term district actually including municipal -in Bahasa Indonesia known as kota - and regency, in Bahasa Indonesia known as kabupaten which is more or less equal to county in US.. The term district applied to all parts of this paper.

\section{Training preparation}

As a part of its activities, the project conducted four-province-wide Training of Trainers (TOT) in Jakarta. The participants are would-be-trainers in each province while the lecturers are Education and Training Consultants, a five-person-team.

The participants are appointed by the Provincial Library. The training materials consists of report writing, information organisation, library management, library service marketing. The obvious difficulties lies in the participants' background. Although most of them are librarian by profession, still some of them the are newly appointed head librarians for public libraries but without library science background. This situation happened owing to the launched regional autonomy policy by the government in which each province, municipality, town, county, district have an independent policy in arranging their house keeping matters except in the field of judicial, police, military, foreign relation, monetary matters. Hence some participants at the TOT programme have various background, ranging from school teachers to family planning supervisor until public market director!

\footnotetext{
${ }^{1}$ This requirements are applicable to community libraries and not to school libraries. For school libraries, actually there are no school librarian or teacher-librarian, the only exists is teacher in charge of library, usually appointed by the head master. Almost all of them never got any professional library training.
} 
Each participant receives training modules in library materials acquisition, organisations, service and promotion and issues in library development. In lieu of the end users are teachers who will be in charge of library, the training modules given to TOT participants are made as simple as possible. For example, for the classification using DDC, the trainers just use the first or second summary, latter on there are demand for further detail classification which are fulfilled by Third Summary. Even the third summary is considered not enough for school libraries especially notation for Indonesian region. They (school teachers in charge of library) asked further detail for Indonesian geographic notation, alas the NLI does not have good classification for Indonesia ${ }^{2}$ !

The TOT program is a train the trainer program - After the four-province-wide training in Jakarta the four-province-wide trainers will train community facilitators. Community facilitators will assist the school teacher in charge of library ${ }^{3}$ in running their libraries as many of the teachers in charge of library have no training in librarianship.

After the training session is over, the project conducted upgrading course at the provincial level. The Education and Training Consultants supervised the upgrading at the provincial level. The next upgrading course are for beneficiary libraries, conducted at the district attended by schoolmasters, community leaders and library personnel. The trainers are TOT programme graduates while the Education and Training Consultants supervise the implementation programmes.

The upgrading course for the beneficiary libraries is followed by library visits to the beneficiary libraries. Almost all beneficiary-school-libraries are visited, albeit various physical and infrastructure obstacles. It was observed that most of the feedback is house keeping matters such as the difficulty in getting the proper books owing to the nonexistence of book shops and satisfaction with the project.

\section{Implementation}

After the training phase, the project then distributed the block grant to the participants for five semesters beginning the year 2002 (Table 1)

Table 1. Financial assistance for the school libraries

\begin{tabular}{|l|l|l|}
\hline Semester & $\begin{array}{l}\text { Single school library } \\
\text { (In Indonesian rupiahs) }\end{array}$ & $\begin{array}{l}\text { Multiple school library } \\
\text { (In Indonesian rupiahs) }\end{array}$ \\
\hline I, 2002 & 5.000 .000 & 7.000 .000 \\
\hline II, 2003 & 3.500 .000 & 5.500 .000 \\
\hline III, 2003 & 3.500 .000 & 5.500 .000 \\
\hline IV, 2004 & 3.500 .000 & 5.500 .000 \\
\hline V, 2004 & 3.500 .000 & 5.500 .000 \\
\hline \multicolumn{2}{|l|}{ Source: Library Development Project,NLI (2004) }
\end{tabular}

\footnotetext{
${ }^{2}$ By the time of writing this paper, NLI revised its former classification, adapting to DDC 22 edition.

${ }^{3}$ The term librarian is rather misleading. Actually they are teachers appointed by the school master to run the library in addition to their normal teaching load. In four provinces there are no administrative personnel who are appointed as school library assistant because the school has no administrative staff and no money to pay the assistant. All administrative affairs are handled by the teachers or school masters.
} 
Single school library means that the school library serves only one school from grade 1 through grade 6 while multiple school library serves two schools or more. For the sake of clarity 1 US \$ is more or less equal to Rp9.500,- The block grants are used for buying books, only $20 \%$ are allowed for library stationery supplies.

After the project has been implemented for two and half years, the Library Development Project sets up two independent teams to evaluate the project performance. The first team is an independent team appointed based on their proposals for the project and the second one consists of five persons who are library education and training consultants.

\section{Performance and Evaluation Team}

Project performance indicators are library usage, library management, user distribution and community support. For school library usage are at least $75 \%$ of the teachers are regularly borrowed books from the school library and there is an increase of $25 \%$ of books borrowed annually. Indicators for library management are there are regular opening hours at least 4 hours during the school days. User distribution indicators cover student participation in assisting the library operations and district support for school libraries. The results are as follows:

- Before 2002, only $20 \%$ of the teachers who used the library and borrow books. During the implementation phase there is an increase of book-borrowing among the teachers to almost $70 \%$ of the total teachers.

- An increase in books borrowed by students. Formerly only $15 \%$ of the books owned by the library schools are charged out, two and half years the number increased into $45 \%$. This is the result of books procured during the project phase.

- An increase of library (opening) hours more than four hours day. Although there in an increase of library hours, there were arguments that 50\% of these library hours are conducted during class time and the students could use the library during the break hours, twice a day for 15 minutes. The Education and Training consultants do not favour the library opening sessions during break hours because this is intended for physical rest. Also, although an increase in post-class-library hours was indicated, many teachers in charge of the library complained because of the long hours after school created more work for which they were not compensated.

- In all four provinces, there are no professional librarians at primary school owing to limited school budget. All administrative tasks are handled by the schoolmaster. For library matters, the schoolmaster appointed one teacher to be responsible on all library matters; sometime there are student assistants to help her/him. Hence the appropriate designation is teacher in charge of library.

- The increase in book budgets resulted in larger book collections. 


\section{Clinical supervision}

Clinical supervision is a supervision to remediate any constraints commonly found in library operations by the teacher in charge of library. The supervision conducted by Education and Training Consultants, began with meeting the Project Implementation Unit, District Library Team who in turn briefed the Community Facilitators on the purpose of clinical supervision. In order to obtain information, the Consultants distributed questionnaires to teacher in charge of library. Among the questions posed are any obstacles found in each library.

The clinical supervision in each district is preceded by a meeting between the tutor, District Library Team (personnel from the public library) and Education and Training Consultants in the district capital. The tutors and personnel from the District Library Team then visited the library appointed as the clinical supervision arranger. Education and Training Consultant(s) attended the clinical supervision meetings albeit few hours. At the clinical supervision, the beneficiary libraries submitted the questionnaires. The beneficiary libraries send two personnel at the meeting, one is the schoolmaster while the second one is the teacher in charge of library or the teacher in charge of library substitute because the former teacher in charge of library has relinquished his/her duties to another teacher who is actually the would-be-teacher in charge of library. The supervision clinical meeting conducted at 27 districts, attended also by Education and Training consultants.

\section{Common problems}

Based on the sites visit, question and answer session and questionnaires, the common problems commonly found among the beneficiary libraries are as follows:

\section{Materials acquisition}

Although each beneficiary school library got block grants for buying books, getting the right books is another difficulty. In the islands of Sumbawa and Bangka, remote parts of South Sumatera, there are no book shops. Most book shops do not send orders by post and in some remote areas, the teacher in charge of the library must travel to purchase books in person. Some travel between eight hours to ten hours by bus. Unfortunately, the Library Development Project does not provide transportation budget. Central Java has relatively good access to many quality book shops.

\section{Book processing}

Although the teacher in charge of library have been trained by the TOT participants, District Library Team and also assisted by Community Facilitators, still there are books, there may be minor errors in processing. In Central Java, South Sumatera and Bangka Belitung, teacher in charge of library are generally able to process the books which they got from the project.

\section{Lack of library statistics}

Not all beneficiary libraries produced statistics -as required by the projects - on book acquisition, loan and borrowing, library visitors, books lost. 


\section{Lack of proper library room}

This situation is commonly found among libraries in some districts in Central Java and West Nusa Tenggara bu not in South Sumatera or Bangka Belitung. The room for library is limited to 3 x 5 metres, most of them are not equipped with chairs. The students sit on the floor.

\section{Problems with the teacher in charge of library}

Almost all teachers in charge of the library are school teachers appointed by the schoolmasters to run the library without formal training in librarianship. These teachers in charge of library are not full time school librarians because she or he still teaches classes. Hence the appointment of teacher in charge of library means extra burden so it is not surprising that there are common book logs, limited library hours.

\section{Problems with bank accounts}

The project send the block grants directly to the beneficiary schools who will open the bank account at certain state banks. Alas the banks not always have branches in subdistricts so the teacher in charge of library must come personally to the bank in the districts because not all bank branches have online facilities. Even if the sub-district bank branches are on-line, electricity is not reliable.

\section{Remedial efforts}

After conducting the in-situ clinical supervision, analysing the questionnaires and discussions with District Library Teams, the Education and Training Consultants proposed some solutions to the beneficiary libraries as follows:

The Education and Training Consultants suggested that book procurement should be coordinated by the public library who will contact the publishers, bookshops and arranges the acquisition. This suggestion has been implemented for districts of Bima and Sumbawa in the island of Sumbawa. For school libraries in Bangka, the Pangkalpinang Public Library invited the book vendors to the public library semi-annual exhibitions which also attended by the teacher in charge of library. On that meeting they will negotiate the buying process and book prices.

Cataloguing and classification are two difficult task for the teacher in charge of library. The Education and Training Consultants suggested a simpler cataloguing procedure. For library house-keeping activities The Education and Training Consultants working together with District Library Team and Community Facilitators solved this problem by teaching the teacher in charge of library in their own libraries. The same approach is applied also for library statistics. The Education and Training consultants also published a simple guide for school library operations.

The problem of teacher in charge of library is the most difficult task. The school master frequently changes the teacher in charge of library although he or she has been trained for school library operations. In that case the new teacher in charge of library begins at square one. The Education and Training Consultants suggested that the District Library Team conduct the training regularly for the teacher in charge of library.

There are some efforts to hire library assistant, financed by the school under guidance of School Committee. This practice has been done in Pangkalpinang, province of Bangka 
Belitung in which School Committee collaborates with village head and other local administration successfully hired library assistant part-time. However, this situation depends on the school capabilities as some of the beneficiary school libraryare, financially not capable to hire library assistant. As mentioned by some school masters from the rural area, "our school is of poor people where a monthly student fee of Rp1000 or about 10 cents is a burden" ${ }^{4}$

\section{Success stories}

Since the early 1970s when the NLI began to operate after political and economic turbulence in 1960s, literature on school librarianship of Indonesia is characterized by a litany of sufferings. Almost librarianship literature in Indonesia always mentioned the same litany such as lack of good reading materials, books locked in cupboard situated in the school master's working room, no adequate budget, hardly any trained professional librarians except in elite schools, erratic library hours. This project changed the litany of suffering but not all. For the first time in $21^{\text {st }}$ century, school masters, education administrators, teachers in charge of library at government primary schools voiced the importance of school library as part of education.

Aside tremendous progress as reported by the performance evaluation team, the Education and Training Consultants also found various micro-success among the beneficiary libraries. These are some of success stories on librarianship in four provinces:

- The project raised the school masters' will and hope to set up better school libraries including fighting for special sties for school libraries. In the provinces South Sumatera and Bangka Belitung, 97\% of school libraries are housed in separate building, formerly intended for school master's official residences or the school janitors' house.

- Muaraenim and Baturaja, the school masters persuaded the district head to replace the school library buildings.

- In Blora District, Central Java a school library serves three villagers twice-weekly in addition to the students and teachers. The teacher in charge of library also writes local folklore and writes local history.

- Two schools in island of Lombok and five schools in the island of Sumbawa established collections very relevant to the local community, including information about medical herbs which have also been linked to lessons.

- In school libraries found in the province of West Nusa Tenggara, some teachers in charge of the library initiated the set up of new books by asking students known for their abilities in writing and or drawing to write stories and illustrations. These stories and illustrations will be bound together for the school library collection. In Central Java, it was reported that there are teachers in charge of library working closely with Non Government Organisations pasted the Bahasa Indonesian translation of Dutch, French and English comics donated by some donors.

- All four provinces feature school library activities in the school wall newspapers.

\footnotetext{
${ }^{4}$ Theoretically, education is free but in fact the school still charges the students, the amount varies.
} 
- Better communication between school libraries and public libraries was indicated.

- Before the project era, there are almost no library extension services for school libraries. After the project implementation, many public libraries launched library extension for the students albeit not all of them are served by mobile library. These services are common in the province of Central Java, random services in other provinces. In Sumbawa Besar, the public library even initiated a pick up service for students from the outer areas, although the vehicle is an open truck!

- There were more subsidies from district administration through various government services. For the first two years after the implementation of the Regional Autonomy Act, school libraries were neglected by the local governments because the school and the library are not revenue generating institutions. This situation changed when the library development project was announced as a soft loan from World Bank then many district heads begin to realise the importance of the school library and also the education although that institutions do not earning monies for the local government.

- In some districts such as Blora, Magelang, Brebes, Purworejo, Kebumen (all in Central Java), Muaraenim (South Sumatera), Pangkalpinang (Bangka Belitung) the local governments initiated local deposit acts after the school libraries denoted lack of local publications at local public libraries.

- This project enabled some of the poverty-stricken-primary schools to set up simple libraries. For librarianship, especially for primary schools, the addition of book collections is a tremendous improvement. For some headmasters, they inspiration to further develop their libraries, willing to lobby parents, communities and the Education Service to assist the library development.

\section{Some issues}

Although there are success stories, there are still some problems that must be addressed. Resource issues are the first problem and these qualifications of these people must also be addressed. School library responsibilities are not considered an educational activity for promotion. Even if a teacher is given the title of teacher librarian it is a job title not officially recognised. She or he must choose her/his profession between a teacher or a librarian. Appointing a professional librarian, those who holds a degree in Diploma of Librarianship ${ }^{5}$ is an impossibility for the primary schools because they are unable to share the burden. This situation is of course an exception in many elite primary schools found in big cities. A case by case solution is hiring an administrative personnel, trained them for one or two week courses or job training in public library, then appoint her/him as assistant school librarian. This solution is found in some districts.

The second issue is the allocated budget for books and periodicals. In central Java, apparently some districts has decided to support the beneficiary schools for book budgets, alas not all districts have the same opinion. No one hopes that the activities triggered by the project will stop because of no financial assistance, albeit the Education and Training consultants predicted that between 25 to $30 \%$ of the participating school

\footnotetext{
${ }^{5}$ Two or three years course after Senior High School
} 
libraries will unable to buy more reading materials in the future owing to financial constraints. The majority of these schools are situated in poor areas where even a student fee of 1000 rupiahs or equal to 10 cent US dollar is a luxury.

The third issue is book acquisition. For school libraries in the province of Central Java going to good book shops is not quite a problems thank to good transportation facility. However, for other three provinces getting to good book shops means 3 to almost 20 hour travel by bus. Ordering by post is another choice albeit the government does not subsidize postal service for books. For book shops and school libraries, mail ordering means additional works and less discount for book buying.

The fourth issue is the continuation of the project. Based on the project progress, there are demands from other provinces for the World Bank soft loan projects for school library development. It is up to the government whether to expand the project to another provinces or not.

\section{Post script}

The NLI decided in 2004 to expand the project one year longer until the end of fiscal year 2005. The beneficiary districts are still the same and one-year period will be used for improving the library services and upgrading the teachers in charge of library. Although the project covered only a few primary school libraries, only 550 school libraries out of more than 66,000 primary schools in all over Indonesia, it sparks the spirit of schoolmasters, education administrators and teachers in charge of library to raise the standard of school library for the students and teachers. The project also inspired another provinces to launch the same projects with central government assistance and direction from the NLI. The project reduced the litany of suffering commonly heard among stake holders of school librarianship. By the time of writing this paper, there are plans to expand the project to another six provinces beginning the fiscal year 2006. 


\section{References}

Amythas Expert \& Associates (2005). The effectiveness study of project implementation final report. Jakarta.

Amythas Expert \& Associates (2005a). Laporan ringkas studi efektivitas Proyek Pengembangan Perpustakaan Umum dan Sekolah. [Brief report on the Development Project for Public and School Libraries effectivity study]. Jakarta.

Education and Training Consultant Team. (2004) Upgrading and training programmes report. Jakarta.

Library Development Project. (2004). Bulletin

Konsultan Pelatihan. (2004). Laporan supervise klinis. [Education and Training Consultants' report on clinical supervision] Jakarta Library Development Project, NLI.

Natadjumena, Rachmat. (November, 2004) Indonesia : status of school library development. Country paper for International Workshop on Information Skills for Learning, Colombo, Sri Lanka, 1 - 5 November 2004. 
Reproduced with permission of the copyright owner. Further reproduction prohibited without permission. 